\title{
Response of Soil Microbes and Soil Enzymatic Activity to 20 Years of Fertilization
}

\author{
Martina Kracmarova ${ }^{1, *}$, Hana Kratochvilova ${ }^{1}$, Ondrej Uhlik ${ }^{1}\left(\mathbb{D}\right.$, Michal Strejcek ${ }^{1}$, \\ Jirina Szakova $^{2} \mathbb{D}$, Jindrich Cerny ${ }^{2} \mathbb{D}$, Pavel Tlustos ${ }^{2}$, Jiri Balik ${ }^{2}$, Katerina Demnerova ${ }^{1}$ \\ and Hana Stiborova $1, *$ \\ 1 Department of Biochemistry and Microbiology, Faculty of Food and Biochemical Technology, \\ University of Chemistry and Technology, Prague, Technicka 3, 16628 Prague 6, Czech Republic; \\ hani.kratochvilova@gmail.com (H.K.); uhliko@vscht.cz (O.U.); strejcem@vscht.cz (M.S.); \\ katerina.demnerova@vscht.cz (K.D.) \\ 2 Department of Agro-Environmental Chemistry and Plant Nutrition, Faculty of Agrobiology, Food and \\ Natural Resources, Czech University of Life Sciences Prague, Kamycka 129, 16521 Prague, Czech Republic; \\ szakova@af.czu.cz (J.S.); cernyj@af.czu.cz (J.C.); tlustos@af.czu.cz (P.T.); balik@af.czu.cz (J.B.) \\ * Correspondence: martina.kracmarova@vscht.cz (M.K.); hana.stiborova@vscht.cz (H.S.)
}

Received: 1 September 2020; Accepted: 1 October 2020; Published: 10 October 2020

\begin{abstract}
Fertilization is a worldwide agricultural practice used in agronomy to increase crop yields. Fertilizer application influences overall soil characteristics, including soil microbial community composition and metabolic processes mediated by microbial enzymatic activity. Changes in the structure of microbial communities and their metabolic activity after long-term fertilization were studied in this research. We hypothesized that the different types of fertilization regimes affect nutrient levels in the soil which subsequently influence the metabolic processes and microbial diversity and community structure. Manure (MF; $330 \mathrm{~kg} \mathrm{~N} /$ ha), sewage sludge at two application doses (SF; $330 \mathrm{~kg} \mathrm{~N} / \mathrm{ha}$ and SF3x; $990 \mathrm{~kg} \mathrm{~N} / \mathrm{ha}$ ) and chemical (NPK; N-P-K nutrients in concentrations of 330-90-300 kg/ha) fertilizers have been applied regularly to an experimental field since 1996. The microbial diversity increased in all soils amended with both organic (MF, SF, SF3x) and chemical (NPK) fertilizers. The shifts in microbial communities were observed, which were mainly caused by less abundant genera that were mostly associated with one or more fertilization treatment(s). Fertilization also influenced soil chemistry and the activity of $\beta$-xylosidase, $\beta$-N-acetylglucosaminidase (NAG), acid phosphatase and FDA-hydrolases. Specifically, all fertilization treatments were associated with a higher activity of $\beta$ xylosidase and lower NAG activity. Only the NPK treatment was associated with a higher activity of acid phosphatase.
\end{abstract}

Keywords: enzymatic activity; $\beta$-glucosidase; $\beta$-xylosidase; $\beta$-N-acetylglucosaminidase; acid phosphatase; fluorescein diacetate hydrolysis; microbial community structure

\section{Introduction}

High crop yield has always been the main goal of agriculture, hence it has also become the most important determinant of soil quality [1]. However, taking into account increased concerns about environmental safety, the concept of soil quality encompasses more factors nowadays. Plant, animal and human health, air and water sustainable quality have been included into the definition of high-quality soil [2]. Since fertilization, tillage and other typical agricultural practices manipulate soil properties, changes in soil quality need to be monitored [3]. Total organic carbon is the most frequently used indicator of soil quality; however, more sensitive and rapid indicators are needed to assess soil quality [4]. There is a long discussion about which particular biological parameters should 
be determined for an efficient assessment of soil quality. Microbial diversity, composition of microbial communities and their enzymatic activity offer an effective and sensitive approach to monitoring soil quality, as they respond quickly to disturbances [2].

Soil is colonized by a wide range of diverse microbial populations. Their higher diversity is associated with better soil quality and stress resistance, since a broad spectrum of metabolic pathways is potentially employed [5]. The majority of the microbes live in the upper part of the soil profile, where the largest amount of organic deposits, air and water is available [6]. It was proved that any disturbances, including fertilizer application, crop rotation, tillage, or contamination, mainly influence this organic horizon and affect microbial communities therein [7-9]. As an example, fertilizer application leads to a cascade of several processes: the first alteration of physicochemical soil properties [10] is followed by changes in microbial diversity or/and microbial community structure [11], which is tightly associated with their metabolic activity and biological function in the soil [12]. An increasing number of studies have showed that the alteration of soil microbial communities has consequences on the soil ecosystem $[13,14]$. Interestingly, low-abundance species rather than the dominant taxa are the main drivers of soil multifunctionality [15]. For instance, Desulfosporosinus with its low abundance of $0.006 \%$ of the total prokaryotic community was detected as an important sulphate reducer in peatlands [16], and low-abundance $(<0.1 \%$ relative abundance) populations were the major drivers of the bacterial composition in the rhizosphere of 19 grassland plant species [17].

Enzymatic transformations play a crucial role in the nutrient cycling in soil. Soil enzymes catalyze the release of inorganic nutrients required for plant growth from organic matter [18] and may be of plant or animal origin, but the primary source are microorganisms [19]. Extracellular microbial enzymes are released into soil from either living or dead cells, and their activity is strongly associated with microbial biomass, community structure, substrate availability, the size of soil particles and environmental conditions [20,21].

While the microbial community structure reflects the functional potential of the soil microbes, their enzymatic activity may be a much more accurate reflection of the processes currently taking place in the soil. Hydrolytic enzymes decompose organic matter, and the rate of decomposition is likely to be influenced by agricultural management. Primary enzymes involved in the carbon cycle, such as $\beta$-glucosidase or $\beta$-xylosidase, are monitored due to their rapid response to changes in the management regime [22]. They exhibit higher activity with the application of sewage sludge and manure, due to their microbial growth-promoting content of cellulose, hemicellulose and lignin [23,24]. Other enzymes have also been reported to be influenced by fertilization, and are monitored in soils to determine the soil biological quality. $\beta-\mathrm{N}$-acetylglucosaminidase (NAG), involved in the N cycle, catalyzes chitin breakdown to amino sugars and is a major source of mineralizable nitrogen in the soil [25]. NAG activity was reported to be higher after the application of sludge to soil, which was explained by an increased fungal biomass [26]. Hydrolases, such as lipases, proteases and esterases, are all able to hydrolyze fluorescein diacetate (FDA), which made the degradation of FDA a generally accepted method in environmental microbiology for measuring total microbial activity [27,28].

This study is a follow up to our previous work in which we described the response of endophytic microbial communities to the long-term fertilization of agricultural soils [29]. Since the community structure was significantly altered, in this study we focused on the metabolic processes happening in some of these fertilized soils. Samples for this study were collected a year and half after the previous study, hence the microbial communities were reanalyzed as well. The objective of this study was to align the changes in the microbial community structure that depended on the application of manure, sewage sludge or NPK with enzymatic activity in these fertilized soils. The activity of five enzymes: $\beta$-glucosidase, $\beta$-xylosidase, NAG, acid phosphatase and FDA hydrolases, was monitored to gain an insight into various pathways of degradation of organic matter in the soil. We hypothesized that organic amendments will be reflected predominantly by enzymes involved in the C-cycle, and the application of organic fertilizers will influence the microbial diversity and community structure partly because of a direct transmission of microbes to the soil. In contrast, NPK amendment was expected to 
predominantly influence the activity of enzymes involved in the $\mathrm{P}$ and $\mathrm{N}$-cycles and promote higher microbial diversity.

\section{Materials and Methods}

\subsection{Experimental Design and Soil Sampling}

The experimental field-plot is located in the Czech Republic (CZE; $49^{\circ} 33^{\prime} 16^{\prime \prime}$ N, 15 21'2" E) and has been regularly fertilized since 1996. Before this year, all field-plots were treated the same way. The experimental soil is characterized as cambisol, with a $\mathrm{pH}$ of $5.27 \pm 0.5$, clay content of $5.84 \%$, silt content of $43.55 \%$ and sand content of $50.61 \%$. The experimental field-plot was fertilized with: (i) sewage sludge (330 kg N/ha, SF), (ii) sewage sludge (990 kg N/ha, SF3x), (iii) manure (330 kg N/ha, MF), (iv) NPK (N-P-K nutrients were 330-90-300 kg/ha, NPK). Non-fertilized soil was used as a control (CF). Potato (Solanum tuberosum L.), winter wheat (Triticum aestivum L.), and spring barley (Hordeum vulgare L.) respectively were planted at the field-plot in three-year rotations. An illustration of the experimental field plot is displayed in Figure S1. According to typical agronomical practice [30], sewage sludge and manure were applied once per three years before potato plowing, and NPK was applied regularly throughout the three-year rotation cycle. Therefore, the application rate of fertilizers was normalized based on the total nitrogen input over the whole three-year rotation period.

Ten months after the last fertilization, in September 2017 after potato harvesting, four bulk soil samples were taken from each fertilized variant (sub-plot, $60 \mathrm{~m}^{2}$ each) from the 0- to 20-cm topsoil layer, homogenized, and three replicates were used for further analysis of microbial communities, enzymatic activities and physicochemical parameters.

\subsection{Physicochemical Soil Analysis}

Soil $\mathrm{pH}$ was determined in a $0.2 \mathrm{~mol} / \mathrm{L} \mathrm{KCl} \mathrm{2:5} \mathrm{w/v} \mathrm{solution} \mathrm{according} \mathrm{to} \mathrm{the} \mathrm{methodology}$ of the Central Institute for Supervising and Testing in Agriculture, Czech Republic [31]. The total carbon and nitrogen in soils were determined by using a CHNS Vario MACRO cube (Elementar Analysensysteme $\mathrm{GmbH}$, Langenselbold, Germany) analyzer equipped with a thermal conductivity detector. Inorganic-N forms $\left(\mathrm{N}_{-} \mathrm{NH}_{4}{ }^{+}\right.$and $\mathrm{N}^{-\mathrm{NO}_{3}}{ }^{-}$) were determined via a SKALAR San Plus System continuous-flow segmented analyzer (Skalar, Netherlands).

The Mehlich III extraction procedure was used to determine the available macro- and micronutrient contents in the soils as follows: $1 \mathrm{~g}$ of soil is extracted with $10 \mathrm{~mL}$ of the extraction mixture $\left(0.2 \mathrm{~mol} / \mathrm{L}\right.$ of $\mathrm{CH}_{3} \mathrm{COOH}+0.25 \mathrm{~mol} / \mathrm{L}$ of $\mathrm{NH}_{4} \mathrm{NO}_{3}+0.013 \mathrm{~mol} / \mathrm{L}$ of $\mathrm{HNO}_{3}+0.015 \mathrm{~mol} / \mathrm{L}$ of $\mathrm{NH}_{4} \mathrm{~F}$ $+0.001 \mathrm{~mol} / \mathrm{L}$ of EDTA) for $10 \mathrm{~min}$ [32]. Each extraction was done in three technical replicates, all the chemicals used were of analytical grade purity, and were purchased from Analytika and Lach-Ner (Neratovice, Czech Republic). For the centrifugation of the extracts, a Hettich Universal $30 \mathrm{RF}$ (Tuttlingen, Germany) device was used. The reaction mixture was centrifuged at $3000 \mathrm{~min}^{-1}$ (i.e., $460 \mathrm{~g}$ ) for $10 \mathrm{~min}$ at the end of each extraction procedure, and the supernatants were kept at $6{ }^{\circ} \mathrm{C}$ prior to the measurement.

To determine the S, P, Zn, and Ca contents in the extracts, inductively coupled plasma-atomic emission spectrometry (ICP-OES) was used with an Agilent 720 (Agilent Technologies Inc., Santa Clara, CA, USA) equipped with a two-channel peristaltic pump, a Struman-Masters spray chamber, and a V-groove pneumatic nebulizer made of inert material (spectrometry parameters were: power: $1.2 \mathrm{~kW}$; plasma flow: $15.0 \mathrm{~L} / \mathrm{min}$; auxiliary flow: $0.75 \mathrm{~L} / \mathrm{min}$; nebulizer flow: $0.9 \mathrm{~L} / \mathrm{min}$ ). Flame atomic absorption spectrometry (F-AAS, Varian 280FS, Varian, Australia; air flow of $13.5 \mathrm{~L} / \mathrm{min}$, acetylene flow of $2.2 \mathrm{~L} / \mathrm{min}$, burner height of $13.5 \mathrm{~cm}$, nebulizer uptake rate of $5 \mathrm{~mL} / \mathrm{min}$ ) was used for $\mathrm{K}$ determination in the extracts. 


\subsection{Enzyme Assays}

The activity of $\beta$-glucosidase, $\beta$-xylosidase, NAG, and acid phosphatase was measured fluorometrically using 4-methylumbelliferyl (MUB) substrates (Table 1, Sigma-Aldrich, St Louis, MO, USA). The total microbial activity was measured using fluorescein diacetate (FDA, Table 1, Sigma-Aldrich, St Louis, MO, USA). The procedure for measuring enzyme activities was adapted from [33]. Briefly, 2 grams of soil was mixed with $50 \mathrm{~mL}$ of acetate buffer $(50 \mathrm{mM}, \mathrm{pH} 5)$ and placed on a horizontal shaker for 2 hours at $28^{\circ} \mathrm{C}(180 \mathrm{rpm}$, incubated in dark). From each sample of soil-buffer slurry, three technical replicates $(200 \mu \mathrm{L})$ were transferred to a microtiter plate and mixed with $50 \mu \mathrm{L}$ of substrate. Seven concentrations of each substrate were always used: 2000, 1500, 1000, 500, 200, 100 , and $10 \mu \mathrm{M}$. Slurry mixed with sterile distilled water and acetate buffer mixed with substrates (of each concentration) were used as negative controls. For better understanding, the reagent mixing procedure is summarized in Table 2. Then, the plate was shaken horizontally for 2 hours under the same conditions as previously. The reaction was stopped by adding $10 \mu \mathrm{L} \mathrm{NaOH}(1 \mathrm{M})$ and incubated for $20 \mathrm{~min}$. The fluorescence intensity was measured using Fluoroskan Ascent (Thermo Fisher Scientific, Waltham, MA, USA) with $360 \mathrm{~nm}$ excitation and $450 \mathrm{~nm}$ emission filters for MUB-linked substrates. When measuring FDA hydrolysis activity, the procedure was slightly different: (i) acetone was used as the solvent of the substrate, (ii) 2 grams of soil was mixed with phosphate buffer (100 mM, pH 5.8) and (iii) $485 \mathrm{~nm}$ excitation and $510 \mathrm{~nm}$ emission filters were used for fluorometric assays.

Table 1. MUB-linked substrates used for enzyme assays.

\begin{tabular}{lll}
\hline \multicolumn{1}{c}{ Substrate } & \multicolumn{1}{c}{ Enzyme } & \multicolumn{1}{c}{ Dissolvent } \\
\hline 4-Methylumbelliferyl- $\beta$-D-glucopyranoside & $\beta$-glucosidase & water \\
4-Methylumbelliferyl- $\beta$-D-xylopyranoside & $\beta$-xylosidase & water \\
4-Methylumbelliferyl-N-acetyl- $\beta$-D-glucosaminide & $\beta$-N-acetyl-hexosaminidase & water \\
Fluorescein diacetate & Total microbial activity & acetone \\
4-Methylumbelliferyl phosphate & Acid phosphatase & water \\
\hline
\end{tabular}

Table 2. Scheme of mixing procedure of soil-buffer slurry with substrate. The slurry of each soil replicate $(\mathrm{A}, \mathrm{B}, \mathrm{C})$ was divided into three technical replicates $(1,2$, and 3$)$ and mixed with different concentrations of substrate.

\begin{tabular}{|c|c|c|c|c|c|c|c|c|c|c|c|}
\hline & \multirow{3}{*}{$\begin{array}{l}\text { Substrate } \\
2000 \mu \mathrm{M}\end{array}$} & \multicolumn{10}{|c|}{$200 \mu 1$} \\
\hline & & \multicolumn{3}{|c|}{$\begin{array}{c}\text { Technical } \\
\text { Replicate } 1\end{array}$} & \multicolumn{3}{|c|}{$\begin{array}{c}\text { Technical } \\
\text { Replicate } 2\end{array}$} & \multicolumn{3}{|c|}{$\begin{array}{c}\text { Technical } \\
\text { Replicate } 3\end{array}$} & \multirow[t]{2}{*}{ Acetate Buffer } \\
\hline \multirow{8}{*}{$50 \mu l$} & & A & B & C & A & B & C & A & B & C & \\
\hline & $1500 \mu \mathrm{M}$ & \multicolumn{9}{|c|}{ Sample fluorescence } & Negative control \\
\hline & $1000 \mu \mathrm{M}$ & & & & & & & & & & of buffer \\
\hline & $500 \mu \mathrm{M}$ & & & & & & & & & & \\
\hline & $200 \mu \mathrm{M}$ & & & & & & & & & & \\
\hline & $100 \mu \mathrm{M}$ & & & & & & & & & & \\
\hline & $10 \mu \mathrm{M}$ & \multicolumn{9}{|c|}{ Quench coefficient } & Reference standard \\
\hline & $\begin{array}{l}\text { Distilled } \\
\text { Water }\end{array}$ & \multicolumn{9}{|c|}{ Negative control of sample } & Blank \\
\hline
\end{tabular}

Enzyme activities for each substrate concentration were calculated according to the equation adopted from [33], in which the weight of oven-dried soil determined after $24 \mathrm{~h}$ at $105^{\circ} \mathrm{C}$ was used. To compare the enzymatic activities of the five monitored enzymes across fertilization treatments, the calculated activities and substrate concentrations were inverted, and the Lineweaver-Burk reciprocal equation was used for the calculation of maximal velocity $\left(V_{\max }\right)$. 


\subsection{DNA Isolation and Molecular Analysis}

Metagenomic DNA was isolated from soil samples using a FastDNA Spin Kit for Soil (MP Biomedicals, Solon, OH, USA) and purified with a Genomic DNA Clean and Concentrator kit (ZYMO Research, Irvine, CA, USA) according to the manufacturer's protocol. The concentration and purity of isolated DNA were measured in a NanoDrop ND-1000 spectrophotometer (NanoDrop Technologies, Wilmington, DE, USA).

The amplification of $16 \mathrm{~S}$ rRNA genes was performed with two polymerase chain reactions (PCRs), the reaction mix and temperature program of which were adopted from [34]. Briefly, the 515 forward (5'-GTGYCAGCMGCNGCGG-3') and 926 reverse (5'-CCGYCAATTYMTTTRAGTTT-3') primers used were targeted to hypervariable regions V4-V5 of the 16S rRNA gene (adapted from [35]). In the first PCR, the $15 \mu \mathrm{L}$ reactions contained: $0.02 \mathrm{U} / \mu \mathrm{L}$ KAPA HiFi HotStart ReadyMix (Kapa Biosystems, Wilmington, MA, USA), $0.3 \mu \mathrm{M}$ of each primer (Sigma-Aldrich, St Louis, MO, USA), template DNA $(\sim 10 \mathrm{ng} / \mu \mathrm{L})$ and water for molecular biology (Sigma-Aldrich, St Louis, MO, USA). The primers for the second PCR were modified with adaptors and internal barcodes [34] and were used at a 1- $\mu \mathrm{M}$ concentration. As the DNA template, $0.5 \mu \mathrm{L}$ of the previous PCR product was used and together with KAPA HiFi HotStart ReadyMix $(0.02 \mathrm{U} / \mu \mathrm{L})$ and water for molecular biology was added into the $25 \mu \mathrm{L}$ final volume. The temperature program for the first PCR was set as follows: $5 \mathrm{~min}$ at $95^{\circ} \mathrm{C}, 20 \mathrm{~s}$ at $98^{\circ} \mathrm{C}, 28-30$ cycles of $15 \mathrm{~s}$ at $56^{\circ} \mathrm{C}, 15 \mathrm{~s}$ at $72{ }^{\circ} \mathrm{C}$ and a final extension of $5 \mathrm{~min}$ at $72{ }^{\circ} \mathrm{C}$. The temperature program for the second PCR was the same with two modifications: (i) the annealing temperature was $50^{\circ} \mathrm{C}$, and (ii) $8-10$ cycles were used for the amplification. The final PCR amplicons were purified with SPRIselect magnetic beads (Beckman Coulter, Miami, FL, USA) and sent in ice packs to the Core Facility for Nucleic Acid Analysis at the University of Alaska Fairbanks for Illumina Miseq platform sequencing, where the DNA concentration was normalized to $1-2 \mathrm{ng} / \mu \mathrm{L}$ using a SequalPrep Kit (Thermo Fisher Scientific, Waltham, MA, USA) before the sequencing process.

Along with the amplicons of soil samples, amplicons of mock communities (artificial community of 12 bacterial strains) were also prepared under the same conditions to set the proper parameters for the subsequent sequence data processing. The mock communities were laboratory prepared according to [36].

\subsection{Data Processing and Multivariate Statistical Analyses}

In the program R [37], raw sequencing data were processed through a pipeline of DADA2 [38], which was modified based on the obtained sequences of the mock community. The sequences were filtered according to automatically calculated quality parameters (using calculateTrunc function), and the primers were trimmed off. After the dereplication step, amplicon sequence variants (ASVs) were inferred from input unique sequences after removing sequencing errors. The forward and reverse denoised reads were merged, and chimeric sequences were removed from the constructed sequence table. Sequences differing by one base were merged, and the more abundant one was kept as valid. The taxonomy was assigned to the average sequence variants (ASVs) using rdp_species_assignment_16 [39]. All sequence data were deposited into the NCBI Short Read Archive under the accession number PRJNA644622.

Further statistical analyses were performed in R, using the phyloseq [40] and vegan [41] packages. ASVs with no assigned taxonomy at the phylum level were removed ( $4 \%$ of all reads), and the dataset was rarefied to the smallest integer (2900). The broadly used alfa-diversity indices (Shannon and Simpson) were calculated, and the differences in the indices between organically (MF, SF, SF3x treatments together), chemically (NPK) and non-treated (CF) soil samples were tested using analysis of variance (ANOVA) and Tukey's HSD test. The ASVs community data were Hellinger transformed. The influence of fertilization treatments on microbial community structure was evaluated with permutational multivariate analysis of variance (PERMANOVA) based on Bray-Curtis distance. The association of prokaryotic communities clustered at the genus level with the fertilization regime was analyzed using canonical correspondence analysis (CCA) and an ANOVA-like permutation test based on CCA. The adjusted $R^{2}\left(R^{2}\right.$ adj $)$ of explained variation was calculated with the RsquareAdj 
function (vegan package). CCA ordinations with displayed samples were used for the visualization of differences between prokaryotic communities in treated soil. CCA ordination with displayed taxa was used to map the genera abundance profile across the treatments, and the genera abundance was divided into four levels based on the quartiles. To identify genera with significantly different abundance in fertilized sub-plots compared to control soils (CF), differential analysis was conducted using the DESeq2 package [42]. To determine statistical significance, the fold change threshold was set to 1.2 and the false discovery rate cutoff was set to 0.1 .

Differences in the $V_{\max }$ and soil physicochemical parameters between fertilization regimes were tested using multiple ANOVAs, and the calculated $p$-values were adjusted with false discovery rate (FDR) correction [43]. The significantly influenced $V_{\max }$ or physicochemical parameters were then applied to Tukey's HSD test for multiple pairwise comparisons, and the results were visualized with a boxplot in which significant differences between two bars were denoted with letters. To determine the size of the effect of the fertilization treatment on $V_{\max }$, an ANOVA-like permutation test for redundancy analysis was conducted and the obtained $R^{2}$ was adjusted with an RsquareAdj function (vegan package).

\section{Results}

\subsection{Response of Soil Microorganisms to Fertilization}

The influence of fertilization on soil microbial diversity was assessed by Shannon and Simpson diversity indices. The diversity of prokaryotes in soil was significantly higher after the application of organic (MF, SF and SF3x; $p_{a d j}$-value $\leq 0.05$ ) and chemical (NPK; $p_{a d j}$-value $\leq 0.1$ ) fertilizers compared to CF. No statistical difference was observed between the microbial diversity of organically and chemically treated soils.

The microbial community structure was significantly associated with the fertilization treatment (PERMANOVA, $p$-value $\leq 0.01$ ). CCA ordination with displayed samples (Figure 1a) shows a clear separation of prokaryotic community structure based on different fertilization treatments ( $p$-value $\leq 0.001)$. The communities in SF and SF3x-treated soils were the most similar to each another. Based on the $R_{a d j}^{2}$, the application of fertilizers contributed to $15.7 \%$ of the variance in the prokaryotic community.

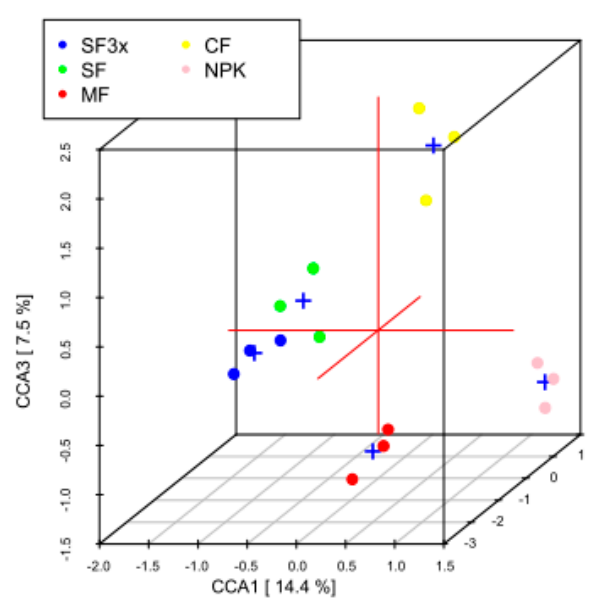

(a)

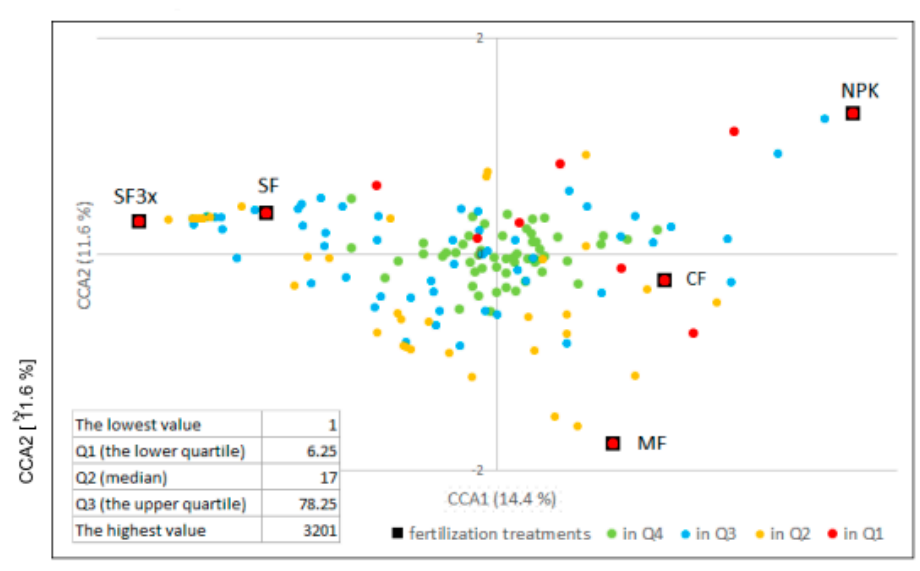

(b)

Figure 1. CCA ordinations of Hellinger-transformed sequence data of prokaryotic communities under different fertilization treatments: control (CF), manure (MF, $330 \mathrm{~kg} \mathrm{~N} / \mathrm{ha}$ ), NPK (NPK, 330-90-330 kg/ha), sewage sludge (SF, $330 \mathrm{~kg} \mathrm{~N} / \mathrm{ha}$ ), sewage sludge (SF3x, $990 \mathrm{~kg} \mathrm{~N} / \mathrm{ha}$ ). Ordination (a) shows sample separation in three-dimensional ordination space. Ordination (b) was constructed with the first two CCA axes, and shows bacterial genera divided into three groups according to their abundance. 
CCA ordination in Figure $1 \mathrm{~b}$ shows the distribution of genera and their abundance in the ordination space. The abundance was divided into four levels based on the quartiles-Q3 was 78.25, Q2 (median) was 17, and Q1 was 6.25. Together with the quartiles, the maximum (3201) and minimum number of reads (1) show an uneven abundance of prokaryotic genera. The genera with higher abundance (from 78.25 to 3,201 ) centered in the ordination space, while genera with low abundance $(<6.25)$ were mostly specific for one of the treatments or their combination.

Differential analysis was used to identify the genera with significantly ( $p_{\text {adj }}$-value $\left.\leq 0.1\right)$ different relative abundance between control (CF) and fertilized soils (Figure 2). Most of the identified genera had significantly higher relative abundance in SF and SF3x- treated soils compared to CF. In contrast to SF treatment, in which the relative abundance of Pseudoxanthomonas, Rhodanobacter, Solirubrobacter and Nitrosospira was significantly higher, the application of SF3x was also associated with a higher relative abundance of Coprothremobacter, Romboutsia, Opitutus, Porphyrobacter, Chitinophaga, Actinoallomurus and Ktedonobacter. Additionally, the relative abundance of Solirubrobacter was also higher in MF-treated soil, and the higher relative abundance of Rhodanobacter and Porphyrobacter, over 20-fold higher, was also observed with the NPK treatment.
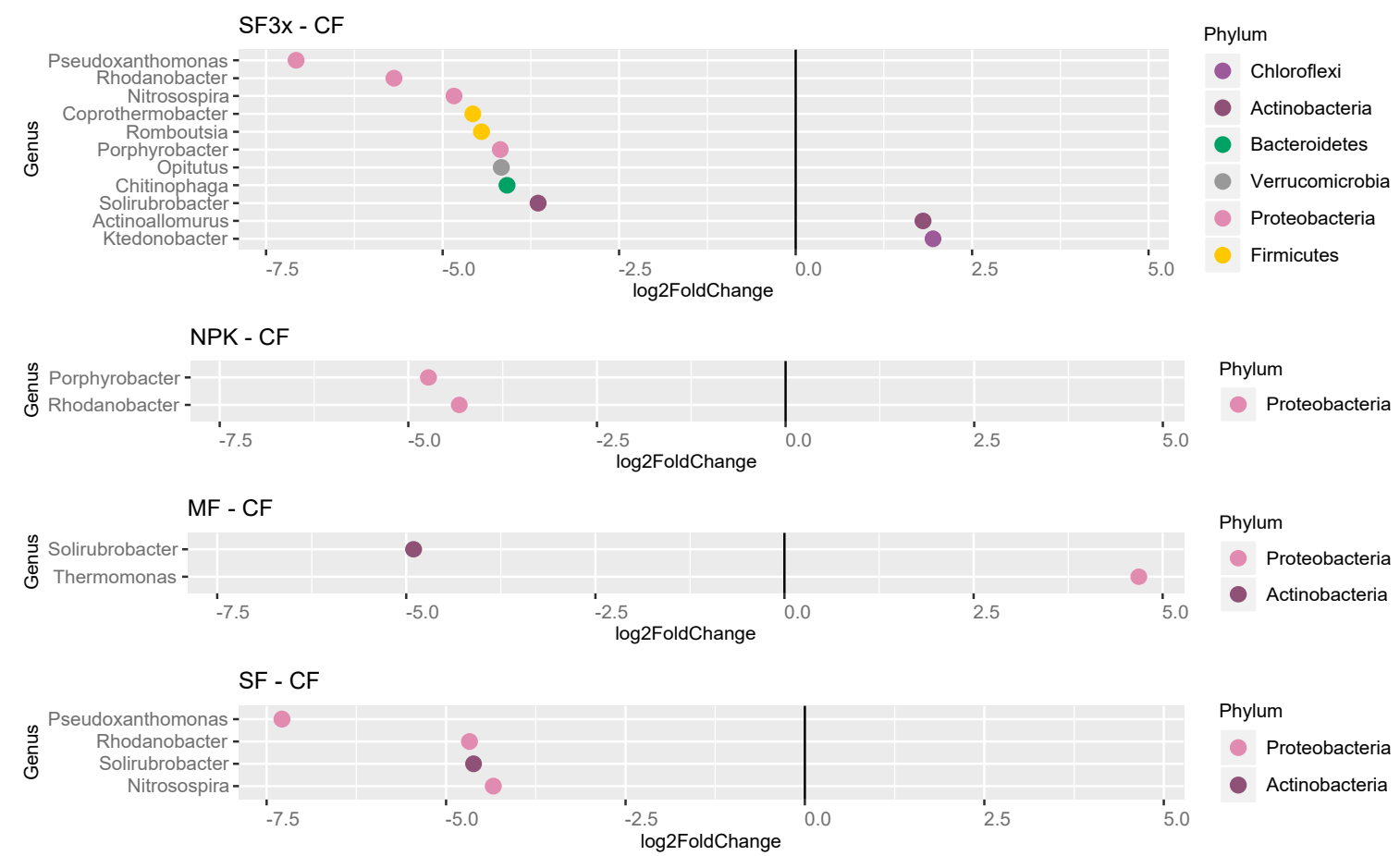

Figure 2. Pairwise comparison (DeSeq analysis) showing prokaryotic genera with significantly ( $p_{a d j}$-value $\left.\leq 0.1\right)$ different relative abundance in fertilizer-treated soils compared to CF. Fertilizers used: control (CF), manure (MF, $330 \mathrm{~kg} \mathrm{~N} / \mathrm{ha}$ ), NPK (NPK, 330-90-330 kg/ha), sewage sludge (SF, $330 \mathrm{~kg} \mathrm{N/ha),}$ sewage sludge (SF3x, $990 \mathrm{~kg}$ N/ha). Negative "log2 Fold Change" values (x-axis) indicate higher abundance of genera in fertilized soils, and positive values indicate higher abundance in $\mathrm{CF}$.

\subsection{Enzymatic Activity in Fertilized Soil}

The $V_{\max }$ values (Table S1) of $\beta$-xylosidase, NAG, acid phosphatase and FDA-hydrolases were significantly associated with fertilization treatments (ANOVA, $p_{a d j}$-value $\leq 0.01$ ), while the $V_{\max }$ value of $\beta$-glucosidase was not. NPK treatment was the only treatment for which the $V_{\max }$ was significantly altered compared to CF (Tukey's HSD test, $p_{a d j}$-value $\leq 0.05$ ) in all enzymes (Figure 3); specifically, the $V_{\max }$ of $\beta$-xylosidase and acid phosphatase was significantly higher, while those of NAG and FDA-hydrolases were significantly lower. Furthermore, the $V_{\max }$ of FDA-hydrolyses was significantly lower for both sewage sludge (SF, SF3x) treatments, the $V_{\max }$ of $\beta$-xylosidase was higher for all fertilized variants, and the $V_{\max }$ of NAG was lower for all fertilized variants compared to CF. To quantify the 
size of the effect of fertilization on $V_{\max }$ data variability, an ANOVA-like permutation test for RDA analysis was performed. Based on $R^{2}{ }_{a d j}$, fertilization explained $66 \%$ of $V_{\max }$ data variability.
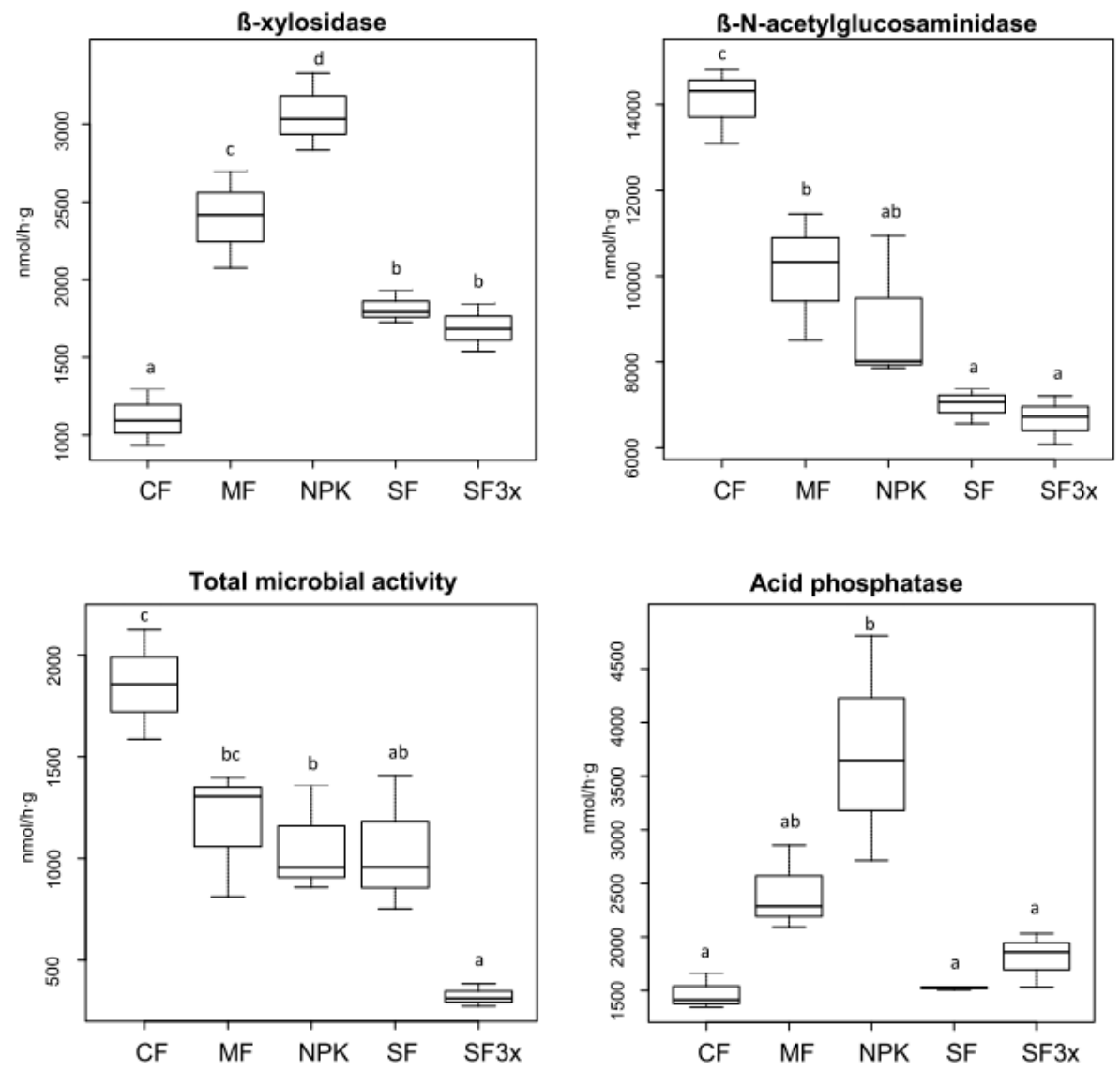

Figure 3. $V_{\max }$ of monitored enzymes in soils amended with: (i) sewage sludge (SF; $330 \mathrm{~kg} \mathrm{~N} / \mathrm{ha}$ ), (ii) sewage sludge (SF3x; $990 \mathrm{~kg} \mathrm{~N} / \mathrm{ha}$ ), (iii) manure (MF; $330 \mathrm{~kg} \mathrm{~N} / \mathrm{ha}$ ), (iv) NPK (NPK; N-P-K nutrients were 330-90-300 kg/ha). Untreated soil was taken as a control (CF). Different letters indicate significant differences between treatments ( $p$-value $\leq 0.05)$ and were assigned according to conducted Tukey HSD post hoc tests.

\subsection{Physicochemical Properties of Soils}

The monitored chemical parameters (Ca, $\mathrm{S}, \mathrm{Zn}$, total $\mathrm{N}, \mathrm{P}, \mathrm{K}, \mathrm{NO}_{3}{ }^{-}, \mathrm{NH}_{4}{ }^{+}$) were found to be significantly associated with fertilization treatments (ANOVA, $p_{a d j}$-value $\leq 0.05$ ), and mostly differed in SF3x and MF treatments (Figure 4) (Tukey's HSD tests, $p_{a d j}$-value $\leq 0.05$ ). The levels of N, K, Zn, P, $\mathrm{NO}_{3}{ }^{-}$and $\mathrm{NH}_{4}{ }^{+}$significantly differed in fertilized soils compared to $\mathrm{CF}$, while the levels of $\mathrm{Ca}$ and $\mathrm{S}$ differed only between NPK and SF3x (Figure 4). The concentration of the soil chemical parameters was the highest in SF3x except for $\mathrm{K}$, the concentration of which was the highest in the MF treatment. The concentration of monitored chemical parameters is summarized in Table S2. 

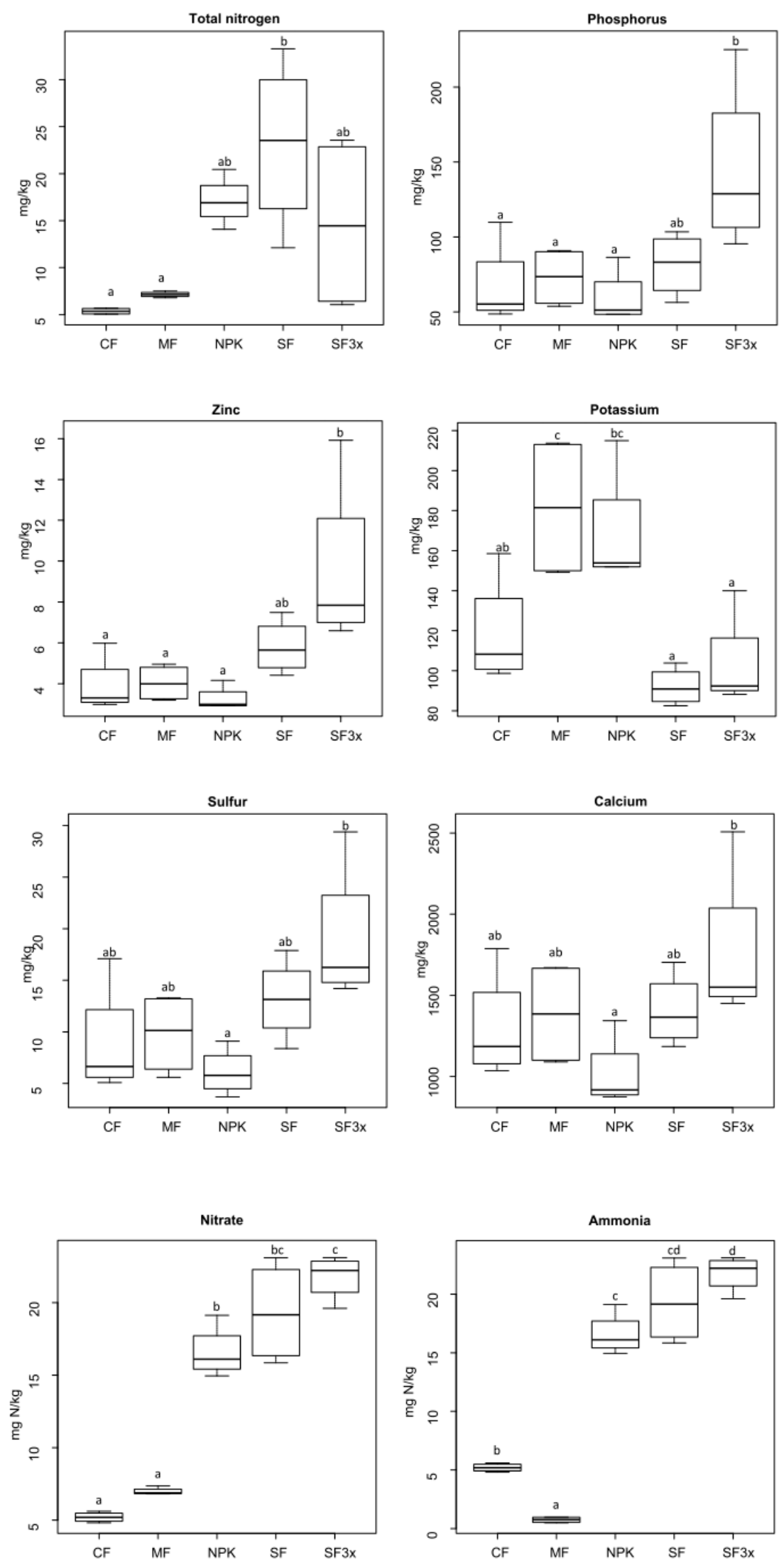

Figure 4. Concentration of N, P, K, S and $\mathrm{Zn}$ in soils amended with fertilizers: (i) sewage sludge (SF; $330 \mathrm{~kg} \mathrm{~N} / \mathrm{ha}$ ), (ii) sewage sludge (SF3x; $990 \mathrm{~kg} \mathrm{~N} / \mathrm{ha}$ ), (iii) manure (MF; $330 \mathrm{~kg} \mathrm{~N} / \mathrm{ha}$ ), (iv) NPK (NPK; N-P-K nutrients were $330-90-300 \mathrm{~kg} / \mathrm{ha}$ ). Untreated soil was taken as a control (CF). Different letters indicate significant differences between treatments ( $p$-value $\leq 0.05$ ). 


\section{Discussion}

In this study, the overall examination of the response of the soil microbial community and their enzymatic activity to 20 years of periodical fertilizer application was evaluated. The long-term application of both organic (MF, SF, SF3x) and chemical (NPK) fertilizers led to a significant increase in prokaryotic diversity in soil compared to the $\mathrm{CF}$, which is in agreement with other studies showing a significant influence of fertilization on soil microbial diversity [44-46]. Although the majority of the studies revealed an increased microbial diversity, especially after organic fertilization $[46,47]$, there is also some evidence of a decline, probably due to the introduction of substances directly reducing richness and evenness, or altering $\mathrm{pH}$ and consequently reducing the diversity $[44,48,49]$. Higher microbial diversity generally promotes the decomposition of organic carbon [50]. This would be in agreement with the higher activity of $\beta$-xylosidase in all fertilized treatments (Figure 3), implying enhanced hydrolysis of xylan, which is a group of hemicelluloses and a very abundant biopolymer in nature. Simple sugars released by the activity of $\beta$-xylosidase are further used by soil microorganisms as a source of carbon [51]. Interestingly, the activity of $\beta$-glucosidase, which is usually referred to as the most sensitive indicator of soil quality and which has been reported to increase with both organic $[52,53]$ and chemical [54] fertilizers, was not found to be affected by the fertilization treatment in this study.

Overall, the fertilization regime explained $66 \%$ of the variability in enzymatic data, showing the enzymes to have a higher sensitivity to soil disturbances than the microbial community structure, for which fertilization only explained $15.7 \%$ of its variability. In addition to the activity of $\beta$-xylosidase, the activity of NAG, acid phosphatase and FDA-hydrolases was significantly associated with fertilization regimes. The activity of NAG was significantly lower for all fertilization treatments compared to $\mathrm{CF}$, with the lowest rates in SF and SF3x treatments. NAG was previously found to play an important role in nitrogen mineralization, and was suggested to be used as an index of the amount of mineralizable nitrogen in soil [55]; however, the NAG activity in our soils was not associated with the amount of total $\mathrm{N}, \mathrm{NO}_{3}{ }^{-}$or $\mathrm{NH}_{4}{ }^{+}$. In fact, although the regular fertilization led to significantly higher total nitrogen levels in SF-treated soil and significantly higher levels of $\mathrm{NO}_{3}{ }^{-}$and $\mathrm{NH}_{4}{ }^{+}$for the SF, SF3x and NPK treatments (Figure 4), the activity of NAG was significantly lower for these treatments than for CF. This inverse correlation in the presence of high levels of $\mathrm{NO}_{3}{ }^{-}$and $\mathrm{NH}_{4}{ }^{+}$was previously explained by the repression of the production of NAG enzyme by inorganic nitrogen [56], which might have taken place in our soils.

As the NPK application is supposed to increase the inorganic phosphorus concentration in soil, it is not surprising that the highest activity of acid phosphatase was detected in NPK-treated soil. Acid phosphatase is considered to be an index of soil quality; its higher activity is attributed to the stimulation of microbial growth, organic matter enrichment and improvement of the P cycle in soil [18]. From this point of view, the NPK treatment seems to stimulate the microbial activity in NPK-treated soils in order to hydrolyze organic phosphorus compounds followed by the release of inorganic $P$.

Sewage sludge and manure application had a lower influence on metabolic processes in the soil compared to NPK in terms of the number of enzymes with influenced activity $\left(V_{\max }\right)$, even though the application of organic fertilizers was associated with significantly higher levels of several soil chemical parameters. Specifically, the concentration of N, P, S, Zn, Ca, nitrate and ammonia was the highest in SF3x, while the K concentration was the highest in MF treatment. However, the soils in this experiment were sampled after the harvest of potatoes, and a single dose of organic fertilizers was applied before potato planting, whereas NPK was regularly applied every year. Thus, a decrease in the element contents in soils treated with organic fertilizers can be anticipated in the next two years, as observed in previous study [57] for sulfur. However, the FDA hydrolysis, which is performed by various hydrolytic enzymes [19], was significantly lower in all fertilization treatments, indicating a lower total soil microbial activity after fertilizer application. This finding is in contrast with our hypothesis that expected an increase in total microbial activity via fertilization, and also in contrast with other studies [58,59]. However, FDA hydrolysis decreases with time [60], suggesting that there 
might have been increased FDA hydrolysis immediately after the fertilizer application, but it lowered over time.

Not only the diversity and enzymatic activity, but also the microbial community structure was significantly associated with fertilization treatments (Figure 1a). Taking into account the abundance profile of the genera (Figure 1b), it seems that the community shifts were more to do with the less abundant genera. The most abundant genera, which centered in the ordination space, indicating that they were similarly distributed across all the treatments, generally have a low influence on soil functioning and the ability to reflect soil disturbances [15]. The association of rare or low-abundance species with one of the fertilization treatments or combination of multiple treatments (Figure $1 \mathrm{~b}$ ) can be explained by several theories, such as a lack of competitiveness with other microbes, waiting for more favorable conditions, or a higher sensitivity to environmental fluctuations, but their important role in biogeochemical processes has been described [61]. While the majority of the community shared similar functions, rare or low abundant species are mainly associated with specific environmental disturbances and provide new or desired biogeochemical traits due to their ability to utilize a limited source of nutrients [61-63].

Most of the differently abundant genera had higher relative abundance in fertilized soils (Figure 2). Opitutus, Chitinophaga and Solirubrobacter had higher relative abundance in organically treated soils (MF, SF and/or SF3x), indicating that their presence might be associated with the higher organic and nutrient content in soil, which is in accordance with [64]. Furthermore, Solirubrobacter was primarily found to be enriched in healthy soils [65]. Other genera which were enriched in SF and SF3x-treated soils Romboutsia, Rhodanobacter, Pseudoxanthomonas, Opitutus and Nitrosospira were previously detected in sewage sludge [66-69], suggesting their possible direct transmission from the fertilizer. Coprothermobacter, the genus which was also enriched in SF3x, is associated with digestion processes in organic wastes treated at high temperatures $[70,71]$. The significantly increased relative abundance of ammonium-oxidizing Nitrosospira in SF3x-treated soil was in accordance with the significantly higher levels of ammonium (Figure 4), which is oxidized to nitrite by Nitrosospira activity [72]. The significant enrichment of such bacteria can indicate that the soil microbiota composition was altered in order to utilize the new input of different organic compounds that were introduced into the soil with the fertilizer application $[73,74]$.

In summary, our data show that fertilization influenced the nutrient status of soil, which was clearly reflected by changes in microbial communities and their enzymatic activities. Both organic and chemical fertilizers promoted the decomposition of organic matter. Our further studies will aim to uncover the microbial community succession over time in these fertilized soils, and the possible transmission of antibiotic resistance genes via organic fertilization. Thus, we will obtain a comprehensive picture of this management practice, which could be beneficial for further decision-making strategies.

Supplementary Materials: The following are available online at http://www.mdpi.com/2073-4395/10/10/1542/s1. Table S1 The $V_{\max }$ values of $\beta$-glucosidase (GLU), $\beta$-xylosidase (XYL), $\beta$-N-acetylglucosaminidase (NAG), acid phosphatase ( $\mathrm{PHO}$ ) and FDA-hydrolases (FDA) under different fertilization treatments: control (CF), manure (MF, $330 \mathrm{~kg} \mathrm{~N} / \mathrm{ha}$ ), NPK (NPK, 330-90-330 kg/ha), sewage sludge (SF, $330 \mathrm{~kg} \mathrm{~N} / \mathrm{ha}$ ), sewage sludge (SF3x, $990 \mathrm{~kg}$ N/ha). Table S2 Physicochemical parameters of soils under different fertilization treatments: control (CF), manure (MF, $330 \mathrm{~kg} \mathrm{~N} / \mathrm{ha}$ ), NPK (NPK, 330-90-330 kg/ha), sewage sludge (SF, $330 \mathrm{~kg} \mathrm{~N} / \mathrm{ha}$ ), sewage sludge (SF3x, $990 \mathrm{~kg} \mathrm{~N} / \mathrm{ha}$ ).

Author Contributions: Conceptualization, H.S. and O.U.; methodology, H.S., O.U. and J.B.; formal analysis, M.K. and M.S.; investigation, M.K. and H.K.; data curation, M.K.; writing-original draft preparation, M.K.; writing-review and editing, O.U., K.D. and H.S.; visualization, M.K.; supervision, H.S. and K.D.; project administration, H.S., P.T. and J.S.; funding acquisition, K.D., P.T., J.B. and J.S.; resources, J.C. All authors have read and agreed to the published version of the manuscript.

Funding: We wish to thank the Czech Science Foundation (project no. 19-02836S) for funding this research, within which the methodology applied for data analysis was developed, and to European Regional Development Fund (project No. CZ.02.1.01/0.0/0.0/16_019/0000845) for founding the sample collection. Further support is acknowledged of the ELIXIR CZ research infrastructure project (Ministry of Education, Youth and Sports of the Czech Republic grant no. LM2015047), specifically for access to computing and storage facilities. 
Acknowledgments: The authors wish to also thank Benjamin John Watson-Jones MEng for English language correction, and the Institute of Arctic Biology's Genomics Core Lab at the University of Alaska Fairbanks for Illumina-sequencing of generated amplicons.

Conflicts of Interest: The authors declare no conflict of interest.

\section{References}

1. Hornick, S.B. Factors affecting the nutritional quality of crops. Am. J. Altern. Agric. 1992, 7, 63. [CrossRef]

2. Schloter, M.; Dilly, O.; Munch, J.C. Indicators for evaluating soil quality. Agric. Ecosyst. Env. 2003, 98, $255-262$. [CrossRef]

3. Mbuthia, L.W.; Acosta-Martínez, V.; DeBruyn, J.; Schaeffer, S.; Tyler, D.; Odoi, E.; Mpheshea, M.; Walker, F.; Eash, N. Long term tillage, cover crop, and fertilization effects on microbial community structure, activity: Implications for soil quality. Soil Biol. Biochem. 2015, 89, 24-34. [CrossRef]

4. Bünemann, E.K.; Bongiorno, G.; Bai, Z.; Creamer, R.E.; De Deyn, G.; de Goede, R.; Fleskens, L.; Geissen, V.; Kuyper, T.W.; Mäder, P.; et al. Soil quality—A critical review. Soil Biol. Biochem. 2018, 120, 105-125. [CrossRef]

5. Kennedy, A.C.; Smith, K.L. Soil microbial diversity and the sustainability of agricultural soils. Plant Soil 1995, 75-86. [CrossRef]

6. Fierer, N.; Allen, A.S.; Schimel, J.P.; Holden, P.A. Controls on microbial CO2 production: A comparison of surface and subsurface soil horizons. Glob. Chang. Biol. 2003, 9, 1322-1332. [CrossRef]

7. Chu, H.; Lin, X.; Fujii, T.; Morimoto, S.; Yagi, K.; Hu, J.; Zhang, J. Soil microbial biomass, dehydrogenase activity, bacterial community structure in response to long-term fertilizer management. Soil Biol. Biochem. 2007, 39, 2971-2976. [CrossRef]

8. Larkin, R.P.; Honeycutt, C.W. Effects of different 3-year cropping systems on soil microbial communities and rhizoctonia diseases of potato. Phytopathology 2006, 96, 68-79. [CrossRef] [PubMed]

9. de la Paz Jimenez, M.; de la Horra, A.; Pruzzo, L.; Palma, M. Soil quality: A new index based on microbiological and biochemical parameters. Biol. Fertil. Soils 2002, 35, 302-306. [CrossRef]

10. Blanchet, G.; Gavazov, K.; Bragazza, L.; Sinaj, S. Responses of soil properties and crop yields to different inorganic and organic amendments in a Swiss conventional farming system. Agric. Ecosyst. Env. 2016, 230, 116-126. [CrossRef]

11. Luo, G.; Rensing, C.; Chen, H.; Liu, M.; Wang, M.; Guo, S.; Ling, N.; Shen, Q. Deciphering the associations between soil microbial diversity and ecosystem multifunctionality driven by long-term fertilization management. Funct. Ecol. 2018, 32, 1103-1116. [CrossRef]

12. Yang, L.; Li, T.; Li, F.; Lemcoff, J.H.; Cohen, S. Fertilization regulates soil enzymatic activity and fertility dynamics in a cucumber field. Sci. Hortic. 2008, 116, 21-26. [CrossRef]

13. Bradford, M.A.; Wood, S.A.; Bardgett, R.D.; Black, H.I.J.; Bonkowski, M.; Eggers, T.; Grayston, S.J.; Kandeler, E.; Manning, P.; Setälä, H.; et al. Discontinuity in the responses of ecosystem processes and multifunctionality to altered soil community composition. Proc. Natl. Acad. Sci. USA 2014, 111, 14478-14483. [CrossRef]

14. Delgado-Baquerizo, M.; Eldridge, D.J.; Ochoa, V.; Gozalo, B.; Singh, B.K.; Maestre, F.T. Soil microbial communities drive the resistance of ecosystem multifunctionality to global change in drylands across the globe. Ecol. Lett. 2017, 20, 1295-1305. [CrossRef] [PubMed]

15. Chen, Q.-L.; Ding, J.; Zhu, D.; Hu, H.-W.; Delgado-Baquerizo, M.; Ma, Y.-B.; He, J.-Z.; Zhu, Y.-G. Rare microbial taxa as the major drivers of ecosystem multifunctionality in long-term fertilized soils. Soil Biol. Biochem. 2020, 141, 107686. [CrossRef]

16. Pester, M.; Bittner, N.; Deevong, P.; Wagner, M.; Loy, A. A 'rare biosphere' microorganism contributes to sulfate reduction in a peatland. Isme J. 2010, 4, 1591-1602. [CrossRef]

17. Dawson, W.; Hör, J.; Egert, M.; van Kleunen, M.; Pester, M. A small number of low-abundance bacteria dominate plant species-specific responses during rhizosphere colonization. Front. Microbiol. 2017, 8, 975. [CrossRef]

18. Adetunji, A.T.; Lewu, F.B.; Mulidzi, R.; Ncube, B. The biological activities of $\beta$-glucosidase, phosphatase and urease as soil quality indicators: A review. J. Soil Sci. Plant Nutr. 2017, 17, 794-807. [CrossRef]

19. Bandick, A.K.; Dick, R.P. Field management effects on soil enzyme activities. Soil Biol. Biochem. 1999, 31, 1471-1479. [CrossRef] 
20. Knight, T.R.; Dick, R.P. Differentiating microbial and stabilized $\beta$-glucosidase activity relative to soil quality. Soil Biol. Biochem. 2004, 36, 2089-2096. [CrossRef]

21. Marx, M.-C.; Kandeler, E.; Wood, M.; Wermbter, N.; Jarvis, S.C. Exploring the enzymatic landscape: Distribution and kinetics of hydrolytic enzymes in soil particle-size fractions. Soil Biol. Biochem. 2005, 37, 35-48. [CrossRef]

22. Ndiaye, E.L.; Sandeno, J.M.; McGrath, D.; Dick, R.P. Integrative biological indicators for detecting change in soil quality. Am. J. Altern. Agric. 2000, 15, 26-36. [CrossRef]

23. Giacometti, C.; Cavani, L.; Baldoni, G.; Ciavatta, C.; Marzadori, C.; Kandeler, E. Microplate-scale fluorometric soil enzyme assays as tools to assess soil quality in a long-term agricultural field experiment. Appl. Soil Ecol. 2014, 75, 80-85. [CrossRef]

24. Li, G.; Zhang, F.; Sun, Y.; Wong, J.W.C.; Fang, M. Chemical evaluation of sewage sludge composting as a mature indicator for composting process. Water Air Soil Pollut. 2001, 132, 333-345. [CrossRef]

25. Ekenler, M.; Tabatabai, M.A. $\beta$-Glucosaminidase activity as an index of nitrogen mineralization in soils. Commun. Soil Sci. Plant Anal. 2004, 35, 1081-1094. [CrossRef]

26. Asensio, V.; Covelo, E.F.; Kandeler, E. Soil management of copper mine tailing soils—Sludge amendment and tree vegetation could improve biological soil quality. Sci. Total Envrion. 2013, 456-457, 82-90. [CrossRef]

27. Adam, G.; Duncan, H. Development of a sensitive and rapid method for the measurement of total microbial activity using fluorescein diacetate (FDA) in a range of soils. Soil Biol. 2001, 33, 943-951. [CrossRef]

28. Green, V.S.; Stott, D.E.; Diack, M. Assay for fluorescein diacetate hydrolytic activity: Optimization for soil samples. Soil Biol. Biochem. 2006, 38, 693-701. [CrossRef]

29. Kracmarova, M.; Karpiskova, J.; Uhlik, O.; Strejcek, M.; Szakova, J.; Balik, J.; Demnerova, K.; Stiborova, H. Microbial communities in soils and endosphere of Solanum tuberosum L. and their response to long-term fertilization. Microorganisms 2020, 8, 1377. [CrossRef]

30. Council Directive 91/676/EEC of 12 December 1991 Concerning the Protection of Waters against Pollution Caused by Nitrates from Agricultural Sources; Council of the European Union: Brussels, Belgium, 1991.

31. Zbíral, J. Comparison of methods for soil pH determination. Rostl. Výroba 2001, 47, 463-467.

32. Mehlich, A. Mehlich 3 soil test extractant: A modification of Mehlich 2 extractant. Commun. Soil Sci. Plant Anal. 1984, 15, 1409-1416. [CrossRef]

33. DeForest, J.L. The influence of time, storage temperature, and substrate age on potential soil enzyme activity in acidic forest soils using MUB-linked substrates and 1-DOPA. Soil Biol. Biochem. 2009, 41, 1180-1186. [CrossRef]

34. Fraraccio, S.; Strejcek, M.; Dolinova, I.; Macek, T.; Uhlik, O. Secondary compound hypothesis revisited: Selected plant secondary metabolites promote bacterial degradation of cis-1,2-dichloroethylene (cDCE). Sci. Rep. 2017, 7. [CrossRef] [PubMed]

35. Walters, W.; Hyde, E.R.; Berg-Lyons, D.; Ackermann, G.; Humphrey, G.; Parada, A.; Gilbert, J.A.; Jansson, J.K.; Caporaso, J.G.; Fuhrman, J.A.; et al. Improved bacterial 16S rRNA gene (V4 and V4-5) and fungal internal transcribed spacer marker gene primers for microbial community surveys. mSystems 2016, 1, e00009-15. [CrossRef] [PubMed]

36. Uhlik, O.; Wald, J.; Strejcek, M.; Musilova, L.; Ridl, J.; Hroudova, M.; Vlcek, C.; Cardenas, E.; Mackova, M.; Macek, T. Identification of bacteria utilizing biphenyl, benzoate, and naphthalene in long-term contaminated soil. PLoS ONE 2012, 7, e40653. [CrossRef]

37. R Core Team R. A Language and Environment for Statistical Computing in R Foundation for Statistical Computing; R Core Team R: Vienna, Austria, 2017.

38. Callahan, B.J.; McMurdie, P.J.; Rosen, M.J.; Han, A.W.; Johnson, A.J.A.; Holmes, S.P. DADA2: High-resolution sample inference from Illumina amplicon data. Nat. Methods 2016, 13, 581-583. [CrossRef]

39. Cole, J.R.; Wang, Q.; Fish, J.A.; Chai, B.; McGarrell, D.M.; Sun, Y.; Brown, C.T.; Porras-Alfaro, A.; Kuske, C.R.; Tiedje, J.M. Ribosomal database project: Data and tools for high throughput rRNA analysis. Nucleic Acids Res. 2014, 42, D633-D642. [CrossRef]

40. McMurdie, P.J.; Holmes, S. Phyloseq: An R package for reproducible Interactive analysis and graphics of microbiome census data. PLoS ONE 2013, 8, e61217. [CrossRef]

41. Oksanen, J.; Blanchet, F.G.; Kindt, R.; Legendre, P.; O’Hara, R.B.; Simpson, G.L.; Solymos, P.; Stevens, M.H.H.; Wagner, H. Vegan: Community Ecology Package. R Package Version 2.5-6; 2019. Available online: https://cran.r-project.org/web/packages/vegan/index.html (accessed on 9 October 2020). 
42. Love, M.I.; Huber, W.; Anders, S. Moderated estimation of fold change and dispersion for RNA-seq data with DESeq2. Genome Biol. 2014, 15, 550. [CrossRef]

43. Benjamini, Y.; Hochberg, Y. Controlling the false discovery rate: A practical and powerful approach to multiple testing. J. R. Stat. Soc. Ser. B Methodol. 1995, 57, 289-300. [CrossRef]

44. Fernandez, A.L.; Sheaffer, C.C.; Wyse, D.L.; Staley, C.; Gould, T.J.; Sadowsky, M.J. Associations between soil bacterial community structure and nutrient cycling functions in long-term organic farm soils following cover crop and organic fertilizer amendment. Sci. Total Envrion. 2016, 566, 949-959. [CrossRef] [PubMed]

45. Hartmann, M.; Frey, B.; Mayer, J.; Mäder, P.; Widmer, F. Distinct soil microbial diversity under long-term organic and conventional farming. Isme J. 2015, 9, 1177-1194. [CrossRef] [PubMed]

46. Zhong, W.; Gu, T.; Wang, W.; Zhang, B.; Lin, X.; Huang, Q.; Shen, W. The effects of mineral fertilizer and organic manure on soil microbial community and diversity. Plant Soil 2010, 326, 511-522. [CrossRef]

47. Ge, Y.; Zhang, J.; Zhang, L.; Yang, M.; He, J. Long-term fertilization regimes affect bacterial community structure and diversity of an agricultural soil in northern China. J. Soils Sediments 2008, 8, 43-50. [CrossRef]

48. Allison, S.D.; Hanson, C.A.; Treseder, K.K. Nitrogen fertilization reduces diversity and alters community structure of active fungi in boreal ecosystems. Soil Biol. Biochem. 2007, 39, 1878-1887. [CrossRef]

49. Zhao, J.; Ni, T.; Li, Y.; Xiong, W.; Ran, W.; Shen, B.; Shen, Q.; Zhang, R. Responses of bacterial communities in arable soils in a rice-wheat cropping system to different fertilizer regimes and sampling times. PLoS ONE 2014, 9, e85301. [CrossRef]

50. Maron, P.-A.; Sarr, A.; Kaisermann, A.; Lévêque, J.; Mathieu, O.; Guigue, J.; Karimi, B.; Bernard, L.; Dequiedt, S.; Terrat, S.; et al. High microbial diversity promotes soil ecosystem functioning. Appl. Envrion. Microbiol. 2018, 84, e02738-17. [CrossRef]

51. Bosetto, A.; Justo, P.I.; Zanardi, B.; Venzon, S.S.; Graciano, L.; dos Santos, E.L.; de Cássia Garcia Simão, R. Research progress concerning fungal and bacterial $\beta$-xylosidases. Appl. Biochem. Biotechnol. 2016, 178, 766-795. [CrossRef]

52. Feng, X.; Ling, N.; Chen, H.; Zhu, C.; Duan, Y.; Peng, C.; Yu, G.; Ran, W.; Shen, Q.; Guo, S. Soil ionomic and enzymatic responses and correlations to fertilizations amended with and without organic fertilizer in long-term experiments. Sci. Rep. 2016, 6. [CrossRef]

53. Piotrowska, A.; Koper, J. Soil $\beta$-glucosidase activity under winter wheat cultivated in crop rotation systems depleting and enriching the soil in organic matter. J. Elem. 2010, 15, 593-600. [CrossRef]

54. Ajwa, H.A.; Dell, C.J.; Rice, C.W. Changes in enzyme activities and microbial biomass of tallgrass prairie soil as related to burning and nitrogen fertilization. Soil Biol. Biochem. 1999, 31, 769-777. [CrossRef]

55. Tabatabai, M.A.; Ekenler, M.; Senwo, Z.N. Significance of enzyme activities in soil nitrogen mineralization. Commun. Soil Sci. Plant Anal. 2010, 41, 595-605. [CrossRef]

56. Olander, L.P.; Vitousek, P.M. Regulation of soil phosphatase and chitinase activity by N and P availability. Biogeochemistry 2000, 49, 175-191. [CrossRef]

57. Kulhánek, M.; Balík, J.; Černý, J.; Sedlář, O.; Vašák, F. Evaluating of soil sulfur forms changes under different fertilizing systems during long-term field experiments. Plant Soil Envrion. 2016, 62, 408-415. [CrossRef]

58. Saha, A.; Basak, B.B.; Gajbhiye, N.A.; Kalariya, K.A.; Manivel, P. Sustainable fertilization through co-application of biochar and chemical fertilizers improves yield, quality of Andrographis paniculata and soil health. Ind. Crop. Prod. 2019, 140, 111607. [CrossRef]

59. Tian, W.; Wang, L.; Li, Y.; Zhuang, K.; Li, G.; Zhang, J.; Xiao, X.; Xi, Y. Responses of microbial activity, abundance, and community in wheat soil after three years of heavy fertilization with manure-based compost and inorganic nitrogen. Agric. Ecosyst. Envrion. 2015, 213, 219-227. [CrossRef]

60. Pane, C.; Villecco, D.; Zaccardelli, M. Short-time response of microbial communities to waste compost amendment of an intensive cultivated soil in southern Italy. Commun. Soil Sci. Plant Anal. 2013, 44, 2344-2352. [CrossRef]

61. Jousset, A.; Bienhold, C.; Chatzinotas, A.; Gallien, L.; Gobet, A.; Kurm, V.; Küsel, K.; Rillig, M.C.; Rivett, D.W.; Salles, J.F.; et al. Where less may be more: How the rare biosphere pulls ecosystems strings. Isme J. 2017, 11, 853. [CrossRef]

62. Banerjee, S.; Schlaeppi, K.; van der Heijden, M.G.A. Keystone taxa as drivers of microbiome structure and functioning. Nat. Rev. Microbiol. 2018, 16, 567-576. [CrossRef]

63. Kurm, V.; van der Putten, W.H.; de Boer, W.; Naus-Wiezer, S.; Hol, W.H.G. Low abundant soil bacteria can be metabolically versatile and fast growing. Ecology 2017, 98, 555-564. [CrossRef] 
64. Polivkova, M.; Suman, J.; Strejcek, M.; Kracmarova, M.; Hradilova, M.; Filipova, A.; Cajthaml, T.; Macek, T.; Uhlik, O. Diversity of root-associated microbial populations of Tamarix parviflora cultivated under various conditions. Appl. Soil Ecol. 2018, 125. [CrossRef]

65. Wang, R.; Zhang, H.; Sun, L.; Qi, G.; Chen, S.; Zhao, X. Microbial community composition is related to soil biological and chemical properties and bacterial wilt outbreak. Sci. Rep. 2017, 7. [CrossRef] [PubMed]

66. Liu, S.; Zhu, N.; Li, L.Y.; Yuan, H. Isolation, identification and utilization of thermophilic strains in aerobic digestion of sewage sludge. Water Res. 2011, 45, 5959-5968. [CrossRef] [PubMed]

67. Stiborova, H.; Strejcek, M.; Musilova, L.; Demnerova, K.; Uhlik, O. Diversity and phylogenetic composition of bacterial communities and their association with anthropogenic pollutants in sewage sludge. Chemosphere 2020, 238, 124629. [CrossRef] [PubMed]

68. Yang, G.; Wang, J. Enhancing biohydrogen production from waste activated sludge disintegrated by sodium citrate. Fuel 2019, 258, 116177. [CrossRef]

69. Zhou, Z.; Qiao, W.; Xing, C.; Shen, X.; Hu, D.; Wang, L. A micro-aerobic hydrolysis process for sludge in situ reduction: Performance and microbial community structure. Bioresour. Technol. 2014, 173, 452-456. [CrossRef]

70. Stiborova, H.; Wolfram, J.; Demnerova, K.; Macek, T.; Uhlik, O. Bacterial community structure in treated sewage sludge with mesophilic and thermophilic anaerobic digestion. Folia Microbiol. (Praha) 2015, 60, 531-539. [CrossRef]

71. Tandishabo, K.; Nakamura, K.; Umetsu, K.; Takamizawa, K. Distribution and role of Coprothermobacter spp. in anaerobic digesters. J. Biosci. Bioeng. 2012, 114, 518-520. [CrossRef]

72. Jiang, Q.Q.; Bakken, L.R. Comparison of Nitrosospira strains isolated from terrestrial environments. Fems Microbiol. Ecol. 1999, 30, 171-186. [CrossRef]

73. Schloter, M.; Nannipieri, P.; Sørensen, S.J.; van Elsas, J.D. Microbial indicators for soil quality. Biol. Fertil. Soils 2018, 54, 1-10. [CrossRef]

74. Ventorino, V.; Pascale, A.; Adamo, P.; Rocco, C.; Fiorentino, N.; Mori, M.; Faraco, V.; Pepe, O.; Fagnano, M. Comparative assessment of autochthonous bacterial and fungal communities and microbial biomarkers of polluted agricultural soils of the Terra dei Fuochi. Sci. Rep. 2018, 8, 14281. [CrossRef] [PubMed]

(C) 2020 by the authors. Licensee MDPI, Basel, Switzerland. This article is an open access article distributed under the terms and conditions of the Creative Commons Attribution (CC BY) license (http://creativecommons.org/licenses/by/4.0/). 